\title{
Wavelength and energy-dispersive X-ray microanalysis with EMA and SEM-EDXRA on thin sections of soils
}

\author{
E. B. A. Bisdom ${ }^{1}$, S. Henstra ${ }^{2}$, E. M. Hornsveld ${ }^{3}$, A. Jongerius ${ }^{1}$ and A. C. Letsch ${ }^{3}$ \\ 1 Soil Survey Institute, Wageningen, Netherlands \\ 2 Technical and Physical Engineering Service, Wageningen, Netherlands \\ ${ }^{3}$ Energy Research Foundation, Petten, Netherlands
}

Accepted: 15 October 1976

Key words: Electron microprobe analysis (EMA); scanning electron microscope (SEM); energy-dispersive X-ray analysis (EDXRA); thin sections.

\section{Summary}

Organic matter, minerals and iron-manganese nodules were studied in thin sections of soils with an electron microprobe analyzer (EMA) and a combination of a scanning electron microscope (SEM) and an energy-dispersive X-ray analyzer (EDXRA). Both instruments were used to estimate the presence and nature of chemical elements in two selected areas, one containing a combination of organic and mineral material and another inside an iron-manganese nodule. This allowed comparison of the performance of both instruments on two types of soil materials.

The detection of organic matter proved problematic. Of the light elements, $\mathrm{N}$ could not be detected with EMA and $\mathrm{O}$ was detected but is not specific to organic matter. EMA could not be used for $C$ in this case because the insulating soil material was covered with carbon for conductivity. SEM-EDXRA only detected heavier elements.

EMA produced somewhat better X-ray images of heavier elements, especially from an iron-manganese nodule. However, with organic material, SEM-EDXRA $\mathrm{X}$-ray images were similar to or slightly better than EMA.

An advantage of SEM-EDXRA over EMA is that the soil material can be analysed at various magnifications with a much higher limit and point analysis can be made of loose material.

For soil material, SEM-EDXRA was better as a routine instrument by which the majority of problems could be solved. EMA can be applied as a complementary instrument. Other microanalytical techniques like the ion microprobe mass analyzer (IMMA) were necessary to analyse light elements in organic material of soils. 


\section{Acronyms}

ED: energy-dispersive

EDXRA: energy-dispersive X-ray analyzer/analysis

EMA: electron microprobe analyzer

IMMA: ion microprobe mass analyzer

SEM: scanning electron microscope

WD: wavelength-dispersive

WDXRA: wavelength-dispersive X-ray analysis.

\section{Introduction}

Two instruments are in common use for the study of unconsolidated soil samples or thin sections, the scanning electron microscope (SEM) and the electron microprobe analyzer (EMA). By SEM, one can make secondary electron images of loose soil material or the surface of a thin section but one cannot detect chemical elements. But EMA measures chemical elements on polished surfaces of thin sections or small impregnated blocks of soil material.

\section{Published studies on EMA and SEM}

EMA and SEM, alone or in combination with other instruments, have been used on soils by many workers. A list of papers, subdivided according to the instruments used, is given below.

\section{$E M A$}

Brewer et al. 1973; Cescas et al. 1968; Childs, 1975; Delvigne \& Martin, 1970; Gillespie \& Elrick, 1968; Gillespie \& Protz, 1972; Hill \& Sawhney, 1971; Innes \& Pluth, 1970; Jeanson, 1966, 1969; Leroux et al. 1970; Quershi et al. 1969; Rutherford, 1969; Sawhney, 1968; Seddoh \& Pedro, 1974; Sweatmann \& Long, 1969; Veen \& Maaskant, 1971.

\section{SEM}

Amiel, 1975; Benayas et al, 1974; Bjørlykke, 1975; Bresson, 1974a; Bruckert et al. 1974; Chang Wang et al. 1974; Clanton et al. 1974; Dormaar, 1974; Driessen \& Schoorl, 1973; Espinoza et al. 1975; Eswaran, 1971, 1972; Eswaran \& de Coninck, 1971; Gallavan \& Greene-Kelly, 1974; Gillott, 1974; Hetier, 1975; Hetier et al. 1974; Hugenroth \& Meyer, 1974; Ingersoll, 1974; Jackson \& Sridhar, 1974; Kilbertus et al. 1973; Legigan \& Le Ribault, 1974; Leneuf, 1972, 1973; Low \& Stuart, 1974; McHardy \& Birnie, 1975 (these authors used a SEM with crystal spectrometer attachment); Miedema et al. 1974; Moinereau \& Roger, 1975; Nahon, 1976; Nahon et al. 1975; Nixon, 1969; Ogunbadejo \& Quigley, 1974; Osman \& Eswaran, 1974; Pierre et al. 1974; Quigley \& Ogunbadejo, 1974; Riezebos, 1974; Riezebos \& van der Waals, 1974; Schmidt-Lorenz, 1974a, b; Sheeran \& Yong, 1974; Singer, 1975; Sridhar et al. 1975; Stoops, 1974; Tan et al. 1975; Tovey, 1974; Tovey \& Kwong 
Yan Wong, 1974; Verheye \& Stoops, 1975; Wilding \& Drees, 1973, 1974; Wilding \& Geissinger, 1973; Wilson, 1975.

\section{$E M A$ and $S E M$}

Bocquier \& Nalovic, 1972; Bresson, 1974b; Righi, 1975; Smart, 1974; Wieder \& Yaalon, 1974.

\section{Purpose of this work}

Our own work concentrated on investigating soil samples with a SEM to which an instrument was attached that could make chemical analyses. This instrument is an EDXRA, which can only analyse heavier elements $(Z \geqslant 11)$. But EMA can analyse chemical elements from boron $(Z=5)$ on, and can therefore test elements like $\mathrm{O}, \mathrm{N}$ and $\mathrm{C}$. SEM-EDXRA, however, has a number of advantages over EMA: 1. SEM-EDXRA can analyse loose soil material and polished surfaces of thin sections and hardened blocks of soil;

2. SEM-EDXRA can measure various elements simultaneously;

3. EMA can analyse elements up to a magnification of about $\times 500$, whereas with SEM-EDXRA analysis up to $\times 10000$ is possible.

The first results of our work with SEM-EDXRA in soil micromorphology were presented at the 'First EDAX European Users Meeting' at Liège, Belgium (Henstra et al., 1973). A description of the methods of analysis with different applications was given in a later publication (Bisdom et al., 1975). With this technique, elements such as $\mathrm{Al}, \mathrm{Si}, \mathrm{Ca}$ and $\mathrm{Fe}$ can be detected in soil material, but to study lighter elements, such as $\mathrm{O}, \mathrm{N}$ and $\mathrm{C}$, we decided to use EMA. Two different areas in thin sections were selected to evaluate EMA for analysis for light elements and to compare analysis for heavier elements by both EMA and SEM-EDXRA. The first area consisted of organic matter, mineral grains and clay-sized material, whereas the second one formed part of an iron-manganese nodule containing mineral grains. The results are described below.

\section{Instruments}

For these experiments, we used an EMA, type Cameca MS 46, and a SEM, type Jeol-JSM-U3 scanning electron microscope, with an EDAX (energy-dispersive $\mathrm{X}$-ray analysis) system. Of these, the EMA is portrayed in Fig. 1, and the various components are indicated. The SEM-EDXRA combination of instruments has been described in a previous study (Bisdom et al., 1975).

Several technical details of EMA and SEM-EDXRA were discussed in the section 'Instruments' by Bisdom et al. (1975). The reader is referred to that paper for an introduction on instruments and some technical principles. The differences between the techniques were summarized in Table 1 of that article. The present paper discusses a few details relevant for comparison of the two instruments. More technical details are given by, for instance, Anderson (1973), Birks (1971), Goldstein \& Yakowitz (1975), Hornsveld (1970), McCrone \& Delly (1973), Reed (1975) and Seiler (1974). 


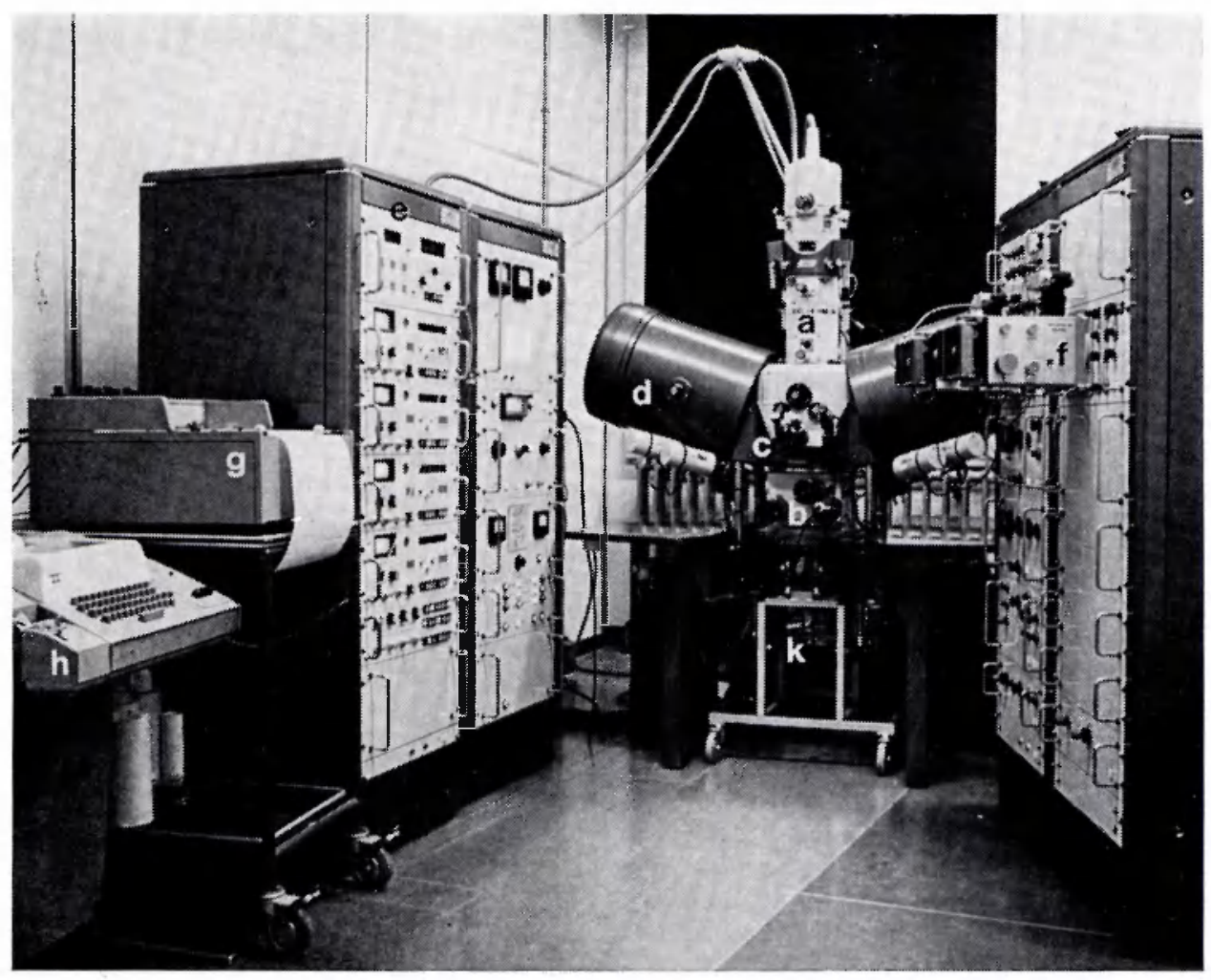

Fig. 1. For the experiments, an electron microprobe analyzer (EMA), type Cameca MS 46, was used. The basic instrument consists of a central optical column (a) with electron gun and electromagnetic lenses and deflexion coils, the specimen chamber (b), an optical microscope (c) for positioning of the area to be analyzed, four X-ray spectrometers (d) enabling analysis of four chemical elements simultaneously.

Four counting channels (e) are coupled to the X-ray spectrometers. Current absorbed by the specimen can be used to obtain a micrograph called an absorbed electron image, the contrast on which is determined by variations in the coefficient of back-scatter of electrons across the specimen surface. Absorbed electron and X-ray images can be displayed on two cathode ray tubes (f) provided with cameras for photography.

An $\mathrm{X}-\mathrm{Y}$ recorder $(\mathrm{g})$ is present for recording line scans. Moreover, the instrument is equipped with an automatic system of analysis digitalized on punched tape by a teletype (h).

This instrument is of a special type adapted for analysis of radioactive specimens by shielding of the specimen chamber and the spectrometers. A vehicle (k) introduces the sample into the specimen chamber.

Microprobes (EMA) are generally equipped with multiple crystal (or wavelengthdispersive, WD) spectrometers. These spectrometers have good spectral resolution in the order of a few electronvolts $(\mathrm{eV})$, which means that neighbouring elements in the periodic system can be separated perfectly. On the other hand, the intensity of the X-ray beam is greatly diminished after reflection off the crystal. The sensitivity of a gas detector is lower than of a $\mathrm{Si}(\mathrm{Li})$ solid-state detector, so that the current 
from the electron beam onto the specimen must be relatively high. In thin sections from plastic-impregnated soils these high currents may cause heating and contaminate the plastic. During this experiment, a beam current of $10^{-7} \mathrm{~A}$ was used, without any observable damage to the specimen.

Another advantage of a WD spectrometer is that in principle elements with low atomic number $(Z \geqslant 5)$ can be detected. The energy of this radiation, however, is low and is easily absorbed by the matrix material. This is one of the reasons that detection of elements with $5 \leqslant Z<13$ can be difficult (Robinson, 1973).

Because the geometric demands for a WD detector assembly are quite severe, specimens for a microprobe must be highly polished. This presents no problem for metal samples, but for plastic-impregnated soil material, where we have substances of various hardness, it is impossible to make thin sections with highly polished scratch-free surfaces which are entirely flat.

With the energy-dispersive (ED) spectrometer from SEM-EDXRA, previously called non-dispersive spectrometer because there is no analysing crystal between the sample and the detector, the X-rays enter the detector unsorted and thus allow detection of all elements (from $Z=11$ ) simultaneously.

Contemporary $\mathrm{ED}$ spectrometers have a $\mathrm{Si}(\mathrm{Li})$ solid-state detector (cooled by liquid nitrogen) with a spectral resolution of about $135 \mathrm{eV}$, which is worse than for a WD spectrometer. However sensitivity is very high so that the current from the electron beam can be greatly diminished (by a factor of about 1000) reducing chances of damage by the beam and contamination of the specimen. During these experiments, a practical beam current of $10^{-10} \mathrm{~A}$ was used.

Between this detector and the vacuum there is a thin (ca $8 \mu \mathrm{m}$ ) beryllium window. From $\mathrm{Na}(Z=11)$ upwards, detection and separation of the elements, unless the concentration is too low, raises no problem. For the elements with $Z<11$, the lowenergy radiation is easily absorbed by the beryllium window. As an example: for the $\mathrm{Na}-\mathrm{K} \alpha$ radiation this $\mathrm{Be}$ window has a transmission of $60 \%$ whereas for $\mathrm{O}-\mathrm{K} \alpha$ radiation this is only $2 \%$. This indicates that elements with $Z<11$ cannot be detected. Windowless detectors can in principle detect elements with lower atomic numbers, but in practice they are still in the experimental stage.

ED detectors have also a higher background level (mainly caused by 'Bremsstrahlung') which gives a much poorer signal-to-noise ratio so that small peaks are submerged into this background.

Because there are no geometrical demands, we can analyze at various magnifications, not only very high (which is impossible with EMA) but also at very low magnifications.

One of the main advantages of ED spectrometers, however, is that we can quickly make a complete qualitative analysis of all sorts of specimens to learn about the principal elements present in the sample.

\section{Examples of the techniques}

Example $l$ concerns analysis of organic matter, excrements, mineral grains and clay-sized material in an Entic Haplorthod (Anon., 1975) near Doorwerth west of 

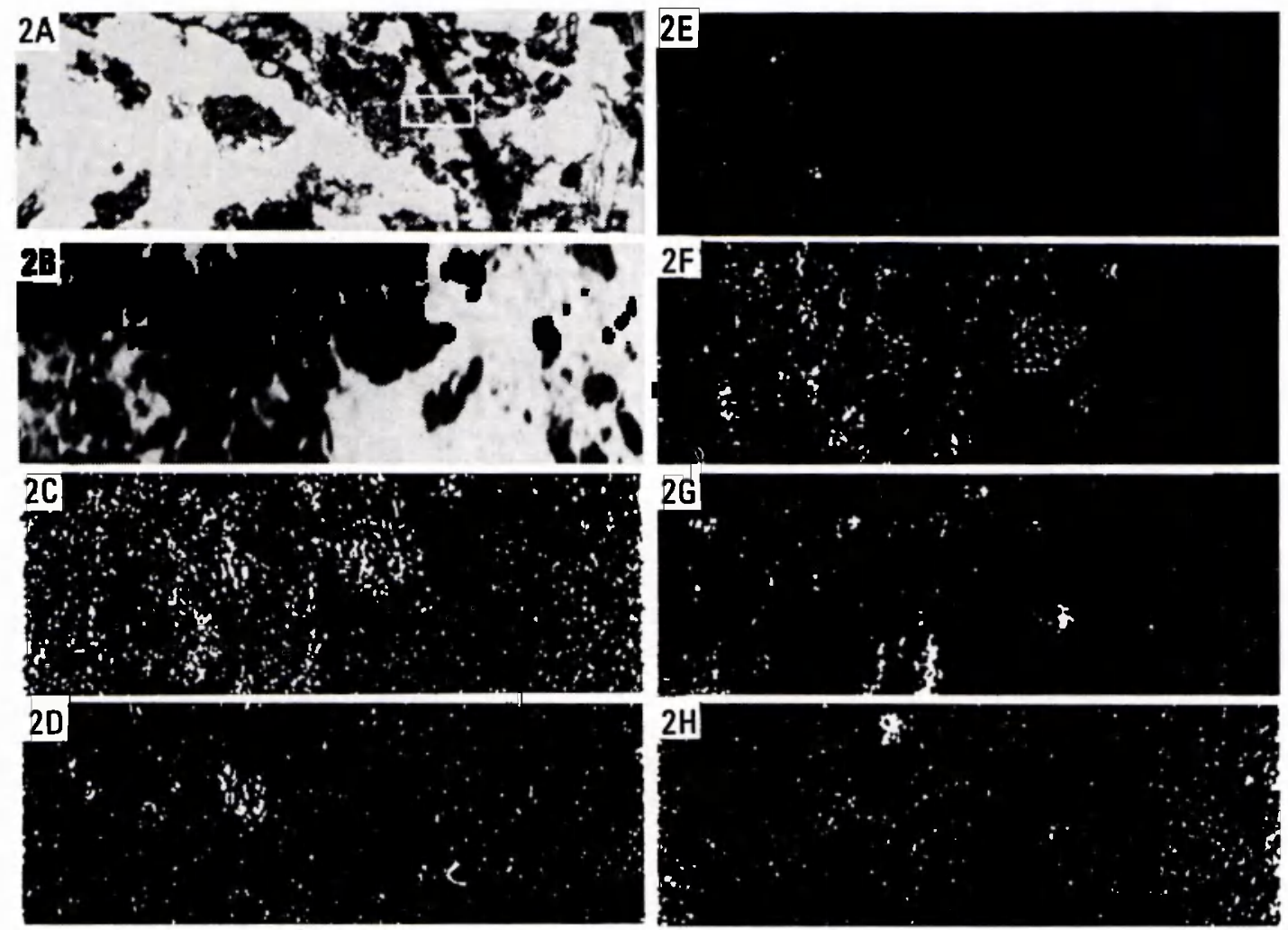

Arnhem, Netherlands, which has been described by de Bakker \& Edelman-Vlam (1976). The results of analysis are portrayed in Fig. 2. Of the light elements, only $O$ could be detected with EMA in both organic and mineral material. $\mathrm{N}$ was not detected because this is always a difficult element to detect because of characteristic long-wave radiation, which is easily absorbed by the matrix of the specimen, by the crystal (after reflection) and by the detector window. C-coating of the thin section prohibited in this case EMA-analysis for this element. Therefore no light elements exclusively present in organic material could be demonstrated by EMA in this sample. Preliminary experiments with the ion microprobe mass analyzer (IMMA) seem promising. Some results will be published shortly in this journal.

EMA X-ray images of the heavier elements in Example 1 are given in Fig. 2C-2H, in which the image of $\mathrm{O}$ (Fig. $2 \mathrm{C}$ ) has also been included. $\mathrm{Na}, \mathrm{Al}, \mathrm{Si}, \mathrm{K}$ and $\mathrm{Fe}$ could be detected, while elements like $\mathrm{P}, \mathrm{S}, \mathrm{Cl}, \mathrm{Ca}$ and $\mathrm{Mn}$ were present in small amounts and were not included in the figure. SEM-EDXRA X-ray images of virtually the same area - the magnification of EMA is $\times 350$ and of SEM-EDXRA $\times 300$ in Fig. 2 and 3 - show AI, Si, K and Fe in Fig. 2K-2N. Sodium was not detected.

The comparison of the X-ray images of both instruments shows somewhat better 

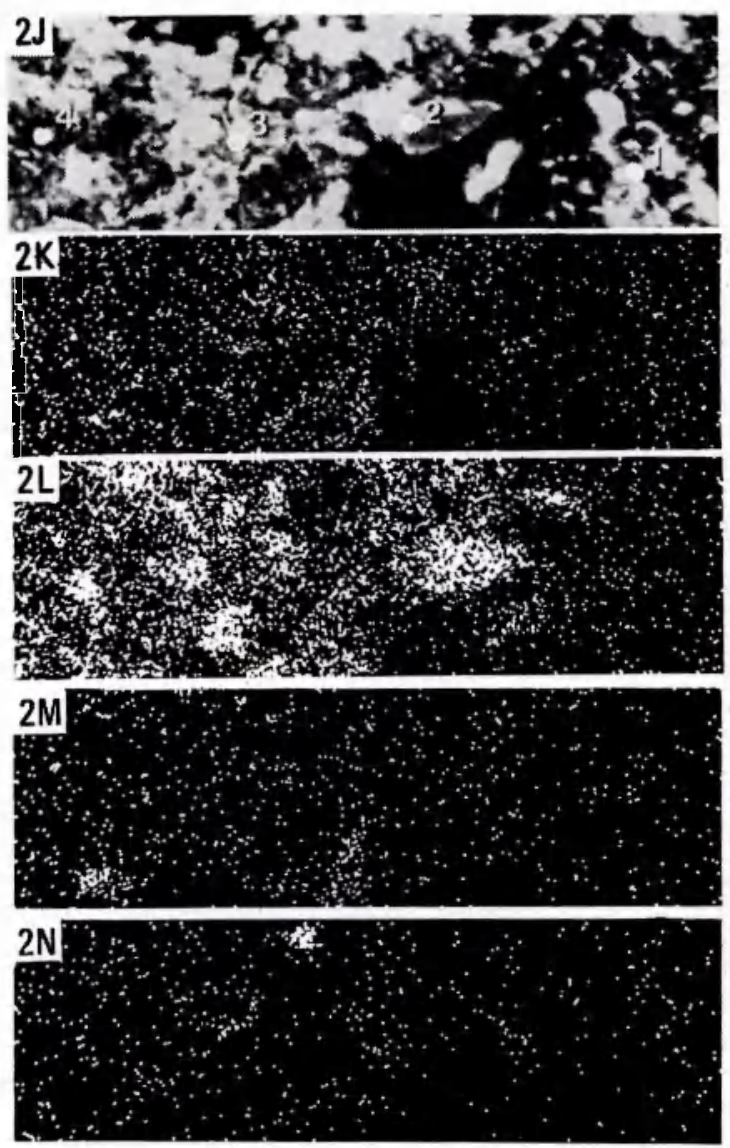

Magnifications: $\times 40$ (Fig. A), $\times 350$ (Fig. B-H), $\times 300$ (Fig. J-N). Elements: O (Fig. C), $\mathrm{Na}$ (Fig. D), Al (Fig. E and K), Si (Fig. F and L), K (Fig. G and M), Fe (Fig. $\mathrm{H}$ and $\mathrm{N}$ ).
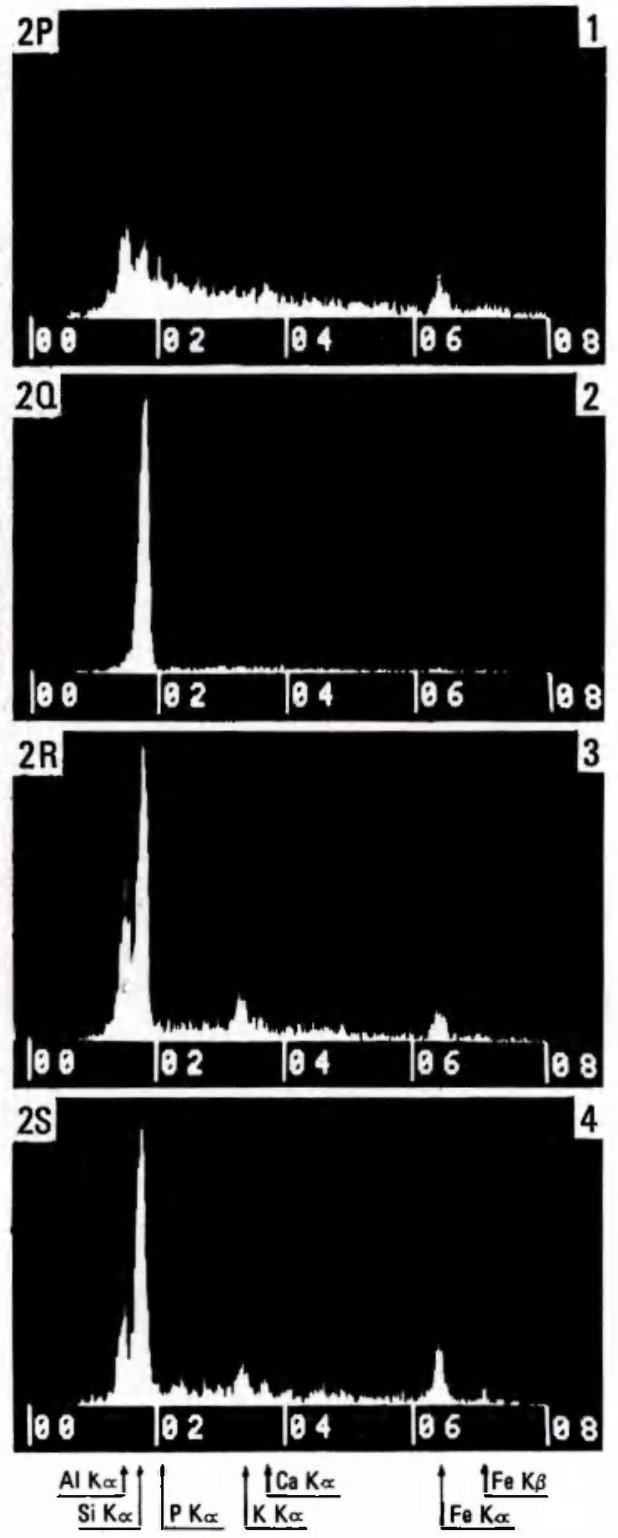

Fig. 2. EMA (Fig. B-H) and SEM-EDXRA (Fig. J-S) techniques with a thin section of a Moder Podzol (Entic Haplorthod) from near Doorwerth, Netherlands. A: Light-microscope photograph of uncovered thin section with area indication from which Fig. B-H are derived. B: Absorbed electron image. C-H: X-ray images of $\mathrm{O}, \mathrm{Na}, \mathrm{Al}, \mathrm{Si}, \mathrm{K}$ and $\mathrm{Fe}$ from soil material in Fig. $\mathrm{B}$. $\mathrm{J}$ : Secondary electron image. Note the reversed contrast of the absorbed electron image (Fig. B) with regard to the SEM image. (Fig. J). K-N: X-ray images of $\mathrm{Al}, \mathrm{Si}, \mathrm{K}$ and $\mathrm{Fe}$ from soil material in Fig. J. P-S: Point analyses at four points (see text) in Fig. J. Point 1: Elements in a plant fragment; point 2: $\mathrm{Si}$ in quartz; points 3-4: analyses of the fine mass in the thin section.

Note: For technical reasons only strips of the originally analysed areas are given in Fig. 2 and 3. 

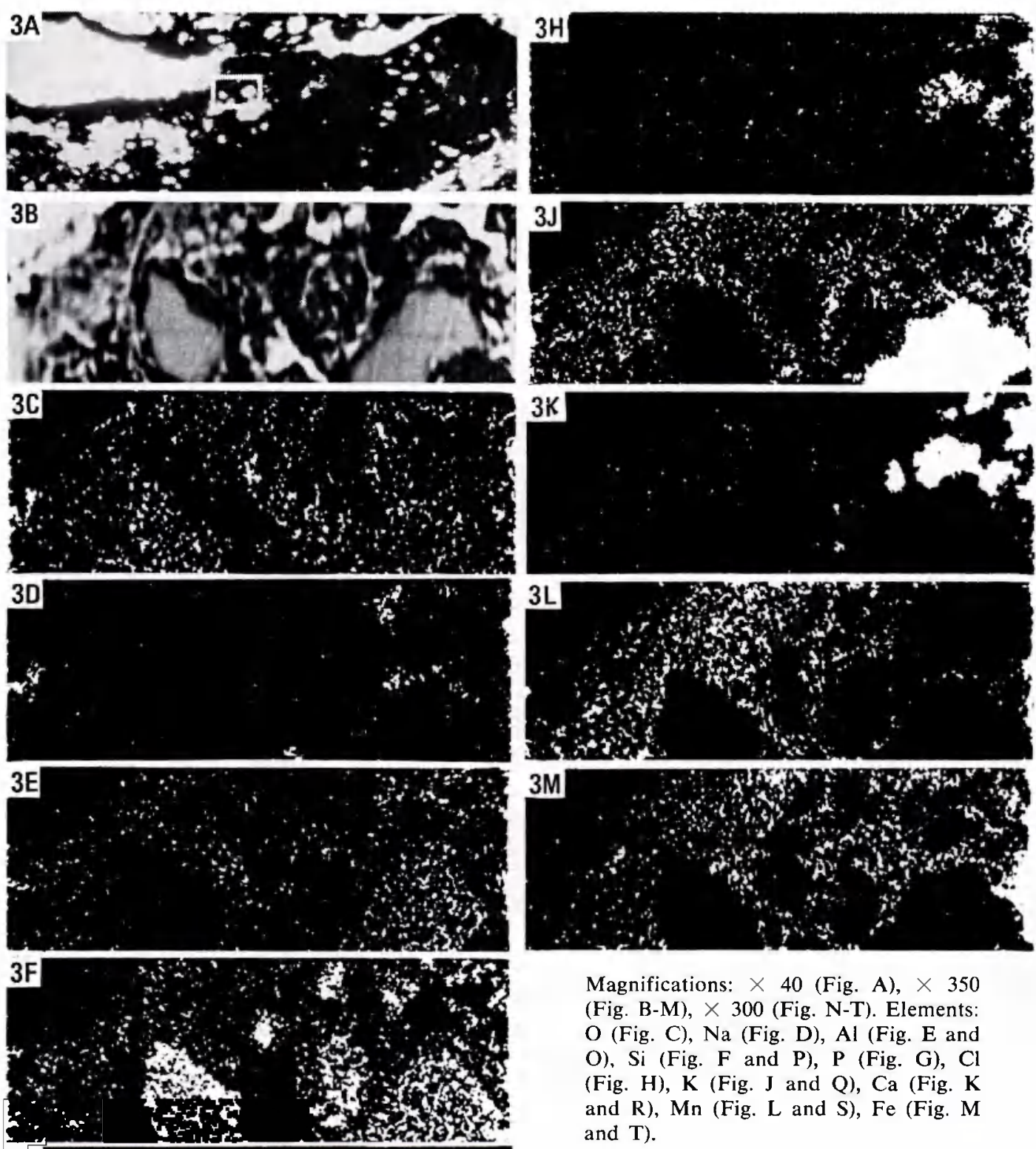

Magnifications: $\times 40$ (Fig. A), $\times 350$ (Fig. B-M), $\times 300$ (Fig. N-T). Elements: $\mathrm{O}$ (Fig. C), Na (Fig. D), Al (Fig. E and O), Si (Fig. F and P), P (Fig. G), Cl (Fig. H), K (Fig. J and Q), Ca (Fig. K and $\mathrm{R}$ ), $\mathrm{Mn}$ (Fig. $\mathrm{L}$ and $\mathrm{S}$ ), $\mathrm{Fe}$ (Fig. $\mathrm{M}$ and $T$ ).

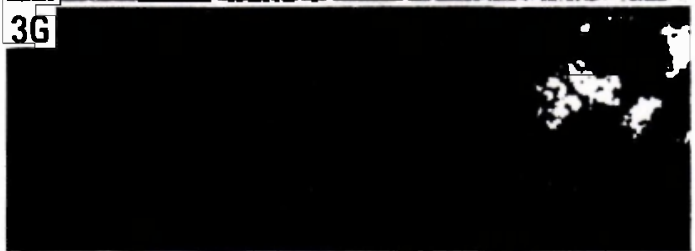

Fig. 3. EMA (Fig. B-M) and SEM-EDXRA (Fig. N-Z) techniques with a thin section of a Poldervaaggrond (Typic Fluvaquent), near Bolsward, Netherlands. A: Light-microscopic photograph of uncovered thin section with area indication whence Fig. B-M are derived. B: Absorbed electron image. C-M: X-ray images of $\mathrm{O}, \mathrm{Na}, \mathrm{Al}, \mathrm{Si}, \mathrm{P}, \mathrm{Cl}, \mathrm{K}, \mathrm{Ca}, \mathrm{Mn}$ and $\mathrm{Fe}$ from nodule material in Fig. B. 

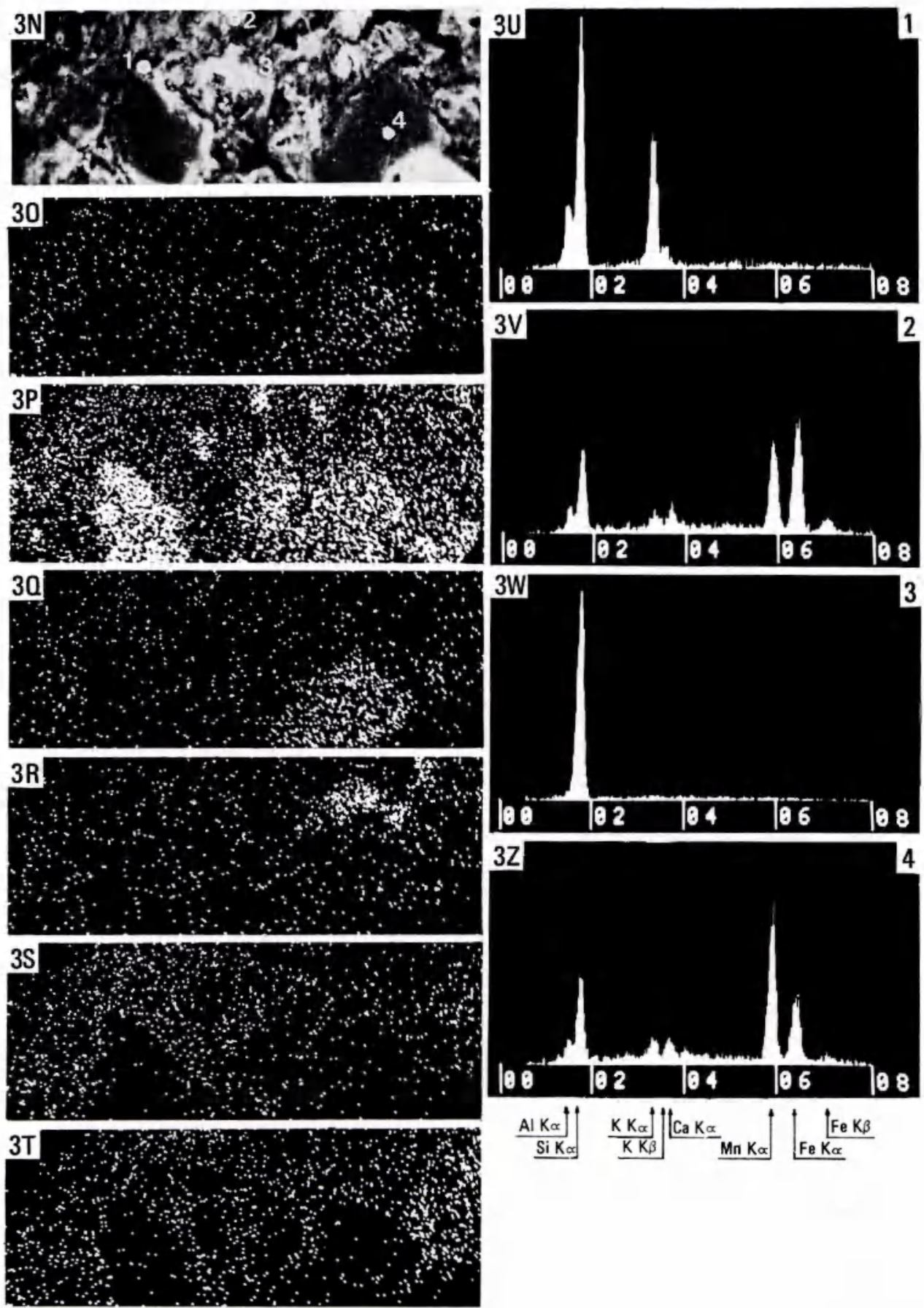

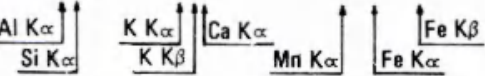

$\mathrm{N}$ : Secondary electron image. Note the reversed contrast of the absorbed electron image (Fig. B) with respect to the SEM image (Fig. N). O-T: X-ray images of $\mathrm{Al}, \mathrm{Si}, \mathrm{K}, \mathrm{Ca}, \mathrm{Mn}$ and $\mathrm{Fe}$ from nodule material in Fig. N. U-Z: Point analyses at four points (see text) in Fig. N. Point 1: elements in a feldspar; points 2 and 4: analyses of a mixture of iron-manganese compounds and clayey material; point $3: \mathrm{Si}$ in quartz. 
results for $\mathrm{Al}$ and $\mathrm{Si}$ with SEM-EDXRA, a comparable outcome with $\mathrm{Fe}$ and a better image of $\mathrm{K}$ with EMA.

Some additional point analyses by SEM-EDXRA are given in Fig. 2P-2S. The position of the points can be found on the secondary electron image - made with SEM - in Fig. 2J. Fig. 2P demonstrates a point analysis in a plant fragment. The $\mathrm{K} \alpha$ peaks of $\mathrm{Al}, \mathrm{Si}, \mathrm{P}$ and $\mathrm{Fe}$ are clearly discernable, whereas those of $\mathrm{Mg}, \mathrm{S}, \mathrm{Cl}$ and $\mathrm{Ca}$ are virtually part of the background. In Fig. 2Q, the silicon of quartz has been measured. Small differences in the fine mass of the thin section are demonstrated in Fig. $2 \mathrm{R}$ and $2 \mathrm{~S} . \mathrm{K} \alpha$ peaks of $\mathrm{Al}, \mathrm{Si}, \mathrm{K}$ and $\mathrm{Fe}$ are present in both figures. Fig. $2 \mathrm{~S}$ shows, however, a little more iron and traces of $\mathrm{S}, \mathrm{Cl}$ and $\mathrm{Ca}$ in the point analyzed. Point analyses generally gave more accurate results than did X-ray images. Consequently we often detected small amounts of elements not discernable with X-ray images. With point analyses, we could compare the height of peaks of individual chemical elements, which allows distinction of minute changes in composition between points in the thin section.

No comparison of SEM-EDXRA and EMA for point analyses has been made. Theoretically, however, point analyses of both instruments are comparable, although for example in the case of $\mathrm{Ba}$ and $\mathrm{Ti}$ where the resolution of SEM-EDXRA is insufficient, EMA is invaluable.

Example 2 for comparison of the performance of the two instruments concerns a part of an iron-manganese nodule of a Typic Fluvaquent (Anon., 1975) near Bolsward, Netherlands, which has been described by de Bakker \& Edelman-Vlam (1976). Light-microscopy showed the presence of predominantly quartz in the nodule and some feldspar. A considerable part of the mineral material in the nodule was masked by iron-manganese compounds.

EMA X-ray images demonstrated the presence of $\mathrm{O}, \mathrm{Na}, \mathrm{Al}, \mathrm{Si}, \mathrm{P}, \mathrm{Cl}, \mathrm{K}, \mathrm{Ca}$, $\mathrm{Mn}$ and $\mathrm{Fe}$ (Fig. 3C-3M). Not included are the images of $\mathrm{Mg}, \mathrm{S}$ and $\mathrm{Ti}$, which were present in small amounts.

SEM-EDXRA X-ray images show Al, Si, K, Ca, Mn and Fe (Fig. 3O-3T). A few point analyses are given in Fig. 3U-3Z. Points 1-4 are indicated in the secondary electron image of Fig. $3 \mathrm{~N}$. $\mathrm{Al}, \mathrm{Si}$ and $\mathrm{K}$ were found in point analysis 1 made from a feldspar. The amounts of elements demonstrated by point analysis with SEMEDXRA are not quantitative. Point 3 (Fig. $3 \mathrm{~W}$ ) is an analysis of quartz. Chemical composition varies slightly in point analyses 2 and 4 made from a mixture of ironmanganese compounds and clayey material. Point 2 contains more iron and less manganese than point 4 , but both points have comparable amounts of $\mathrm{Al}, \mathrm{Si}, \mathrm{K}$ and $\mathrm{Ca}$.

In this example, the quality of the EMA X-ray images was superior.

\section{Conclusions}

These experiments indicate that SEM-EDXRA gives somewhat better X-ray images than EMA in the thin section with organic matter. The opposite was true, however, with the iron-manganese nodule, perhaps because of differences in the applied beam 
current and in composition of the tested materials.

The detection of light elements in organic material with EMA gave poor results. Consequently another technique for analysis of light elements in thin sections had to be found, and we did some preliminary tests with IMMA.

SEM-EDXRA can analyse material for chemical elements up to a magnification of $\times 10000$, whereas EMA has a maximum of about $\times 500$. Also useful is that SEM-EDXRA can analyse loose soil materials by point analysis.

For these reasons, SEM-EDXRA is preferred to EMA as a general instrument for routine soil analysis. EMA has advantages for certain uses. For analysis of light elements, one needs instruments like IMMA.

\section{References}

Amiel, A. J., 1975. Progressive pedogenesis of eolianite sandstone. J. Sedim. Petr. 45 (2): 513-519. Anderson, C. A. (Ed.), 1973. Microprobe analysis. John Wiley, New York, 571 pp.

Anonymous, 1975. Soil taxonomy: a basic system of soil classification for making and interpreting soil surveys. U.S. Soil Survey Staff, Agricultural handbook No 436, Soil Conservation Service, U.S. Department of Agriculture, Washington, D.C., 754 pp.

Bakker, H. de \& A. W. Edelman-Vlam, 1976. De Nederlandse bodem in kleur. Stiboka/Pudoc, Wageningen, Netherlands, $148 \mathrm{pp}$.

Benayas, J., J. Alonso \& E. Fernandez Caldas, 1974. Effect of the ecological environment on the micromorphology and mineralogy of andosols (Tenerife Island). In: G. K. Rutherford (Ed.), Soil microscopy, pp. 306-319. Limestone Press, Kingston, Ontario, Canada.

Bisdom, E. B. A., S. Henstra, A. Jongerius \& F. Thiel, 1975. Energy-dispersive X-ray analysis on thin sections and unimpregnated soil material. Neth. J. agric. Sci. 23 (2): 113-125.

Birks, L. S., 1971. Electron probe microanalysis, 2nd ed. Wiley/Interscience, New York, 190 pp.

Bjørlykke, K., 1975. Mineralogical and chemical changes during weathering of acid and basic rocks in Uganda. Norsk geol. Tidsskr. 55 (1): 81-89.

Bocquier, G. \& Lj. Nalovic, 1972. Utilisation de la microscopie électronique en pédologie. Cah. ORSTOM, Sér. Pédol. 10 (4): 411-434.

Bresson, L. M., 1974a. A study of integral microscopy; rubefaction under wet temperate climate in comparison with Mediterranean rubefaction. In: G. K. Rutherford (Ed.), Soil microscopy, pp. 526-541. Limestone Press, Kingston, Ontario, Canada.

Bresson, L. M., 1974b. Rubéfaction récente des soils sous climat tempéré humide, sequence évolutive sur fluvioglaciaire calcaire dans le Jura méridionale - étude microscopie integrée. Thèse, Université de Paris VI, 197 pp.

Brewer, R., R. Protz \& J. A. McKeague, 1973. Microscopy and electron microprobe analysis of some iron-manganese pans from Newfoundland. Can. J. Soil Sci. 53 (4): 349-361.

Bruckert, S., J. M. Hetier \& F. Gutierrez, 1974. Dynamique de l'humification des andosols du Massif Central Français et des îles Canaries: caractérisation physico-chimique des complexes organo-minéraux. Bull. Ass. fr. Et. Sol 4: 225-245.

Cescas, P. M., E. H. Tyner \& L. J. Gray, 1968. The electron microprobe X-ray analyzer and its use in soil investigation. Adv. Agron. 20: 153-198.

Chang Wang, J. L. Nowland \& H. Kodama, 1974. Properties of two fragipan soils in Nova Scotia including scanning electron micrographs. Can. J. Soil Sc. 54 (2): 159-170.

Childs, C. W., 1975. Composition of iron-manganese concretions from some New Zealand soils. Geoderma 13 (2): 141-152.

Clanton, U. S., D. S. McKay \& G. H. Ladle, 1974. Micromorphology of lunar regolith particles. In: G. K. Rutherford (Ed.), Soil microscopy, pp. 642-654. Limestone Press, Kingston, Ontario, Canada.

Delvigne, J. \& H. Martin, 1970. Analyse à la microsonde électronique de l'altération d'un 
plagioclase en kaolinite par l'intermédiaire d'une phase amorphe. Cah. ORSTOM, Sér. Géol. 2 (2): 259-295.

Dormaar, J. F., 1974. Scanning electron microscopy as applied to organic-mineral complexes in alkaline extracts of soil. Proc. Soil Sci. Soc. Am. 38 (4): 685-686.

Driessen, P. M. \& R. Schoorl, 1973. Mineralogy and morphology of salt efflorescences on saline soils in the Great Konya Basin, Turkey. J. Soil Sci. 24 (4): 436-442.

Espinoza, W., R. H. Rust \& R. S. Adams Jr, 1975. Characterization of mineral forms in andepts from Chile. Proc. Soil Sci. Soc. Am. 39 (3) 556-561.

Eswaran, H., 1971. Electron scanning studies of the fabric of fracture surfaces. Proc. Soil Sci. Soc. Am. 35 (5): 787-790.

Eswaran, H., 1972. Morphology of allophane, imogolite and halloysite. Clay Minerals 9: 281-285.

Eswaran, H. \& F. de Coninck, 1971. Clay mineral formations and transformations in basaltic soils in tropical environments. Pedologie 21 (2): 181-210.

Gallavan, R. C. \& R. Green-Kelly, 1974. The effect of the evaporation of entrained liquid on soil fabric. J. Soil Sci. 25 (4): 449-504.

Gillespie, J. E. \& D. E. Elrick, 1968. Micromorphological characteristics of an Oneida soil profile. Can. J. Soil Sci. 48: 133-142.

Gillespie, J. E. \& R. Protz, 1972. The micromorphology and electron microprobe analysis of two residual soils one developed on granite the other on marble, in Peterborough country, Ontario. Can. J. Soil Sci. 52: 79-89.

Gillott, J. E., 1974. Methods of sample preparation for microstructural analysis of soils. In: G. K. Rutherford (Ed.), Soil microscopy, pp. 143-164. Limestone Press, Kingston, Ontario, Canada.

Goldstein J. I. \& H. Yakowitz (Ed.), 1975. Practical scanning electron microscopy. Electron and ion microprobe analysis. Plenum Press, New York. 582 pp.

Henstra, S., E. B. A. Bisdom, A. Jongerius \& F. Thiel, 1973. Energy-dispersive analysis on thin sections of soils. First EDAX European Users Meeting (Liège, September, 1973). EDAX Editor 3 (1): 5-6.

Hetier, J. M., 1975. Formation et évolution des andosols en climat tempéré. AO-CNRS-11194, $234 \mathrm{pp}$.

Hetier, J. M., F. G. Jerez \& S. Bruckert, 1974. Morphoscopie et composition des complexes organo-minéraux des andosols. C.r. Acad. Sci., Paris Sér. D 278: 2735-2737.

Hill, D. E. \& B. L. Sawhney, 1971. Electron microprobe analysis of soils. Soil Sci. 112 (1): 32-38.

Hornsveld, E. M., 1970. Microanalyse met een elektronensonde. Atoomenergie en haar Toepassingen 12 (12): 321-328.

Hugenroth, P. \& B. Meyer, 1974. Umsetzungsraten calcitischer und dolomitischer Düngemergel unterschiedlicher Vermahlungsgrades in Böden verschiedener Körnung. Landw. Forsch. 30 (1) (Sonderh.): 160-176.

Ingersoll, R. V., 1974. Surface textures of first cycle quartz sandgrains. J. Sedim. Petr. 44 (1): 151-157.

Innes, R. P. \& D. J. Pluth, 1970. Thin section preparation using an epoxy impregnation for petrographic and electron microprobe analysis. Proc. Soil Sci. Soc. Am. 34: 483-485.

Jeanson, C., 1966. Essai de pédozologie expérimentale: Morphologie d'un sol artificiel structuré par les lombricidés. Mém. Mus. Hist. nat., Ser. A 46 (3): 209-357.

Jeanson, C., 1969. Répartition du fer dans un sol artificiel. Etude à la microsonde électronique. In: Proc. 3rd int. Work. Meet. Soil Micromorphol. Zeszyty Problemowe Postepów Nauk Rolniczych: 77-88.

Jackson, M. L. \& K. Sridhar, 1974. Scanning electron microscopic and X-ray diffraction study of natural weathering of phlogopite through vermiculite to saponite. Proc. Soil Sci. Soc. Am. 38 (5): 843-847.

Kilbertus, G., F. Mangenot \& O. Reisinger, 1973. Etude de la décomposition naturelle et expérimentale des feuilles de Brachypodium pinnatum P.B. Programme Biologique international. Recherche Coopérative sur programme C.N.R.S. No 40. Ecologie du Sol, Extrait du Volume III: p. 151-193. 


\section{X-RAY MICROANALYSIS ON THIN SOIL SECTIONS}

Legigan, P. \& L. le Ribault, 1974. Evolution des quartz dans un podzol humo-ferrugineux développé sur le sable des Landes. C.r. Acad. Sci., Paris, Sér. D 279: 799-802.

Leneuf, N., 1972. Aspects microscopiques de la surface de grains de quartz du continental terminal de Cote D'Ivoire. Cah. ORSTOM, Géol. 4 (1): 53-65.

Leneuf, N., 1973. Observations stéréoscopiques sur les figures de corrosion du quartz dans certaines formations. Cah. ORSTOM, Pédol. 11 (1): 43-51.

Leroux, J., C. I. Rich \& P. H. Ribbe, 1970 . Ion selectivity by weathered micas as determined by electron microprobe analysis. Clays \& Clay Miner. 18 (6): 333-338.

Low, A. J. \& P. R. Stuart, 1974. Micro-structural differences between arable and old grassland soils as shown in the scanning electron microscope. J. Soil Sci. 25 (2): 135-137.

McCrone, W. C. \& J. G. Delly, 1973. The particle atlas, 2nd ed. Ann Arbor Science Publ., Michigan, 4 vols.

McHardy, W. J. \& A. C. Birnie, 1975. Scanning electron microscope studies of a surface water gley. J. Soil Sci., 26 (4): 426-431.

Miedema, R., A. G. Jongmans \& S. Slager, 1974. Micromorphological observations on pyrite and its oxidation products in four holocene alluvial soils in the Netherlands. In: G. K. Rutherford (Ed.), Soil microscopy, pp. 772-794. Limestone Press, Kingston, Ontario, Canada.

Moinereau, J. \& L. Roger, 1975. Andosols, sols podzolisés, sols andiques et sols bruns. Séquence sur matériaux basaltiques dans le Velay oriental et le Vivarais (Massif Central, France). Bull. Ass. fr. Et. Sol 4: 295-314.

Nahon, D., 1976. Iron crusts and calcareous crusts in Western Senegal and in Mauritania evolutive systems: Geochemistry, structures relationships and co-existence. Abstract, doctorate thesis. Trav. Lab. Sci. Terre, St Jérôme, Marseille, Sér. A, No 10, 8 pp.

Nahon, D., H. Paquet, A. Ruellan \& G. Millot, 1975. Encroûtements calcaires dans les altérations des marnes Éocènes de la falaise de Thiès (Sénégal). Organisation morphologique et minéralogie. Sci. Géol. Bull. 28 (1): 29-46.

Nixon, W. C., 1969. Scanning electron microscopy. Contemp. Phys. 10 (1): 71-96.

Ogunbadejo, T. A. \& R. M. Quigley, 1974. Compaction of weathered clays near Sarnia, Ontario. Canad. Geotech. J. 11 (4): 642-647.

Osman, A. \& H. Eswaran, 1974. Clay translocation and vertic properties of some red mediterranean soils. In: G. K. Rutherford (Ed.), Soil microscopy, pp. 848-857. Limestone Press, Kingston, Ontario, Canada.

Pierre, J. F., G. Kilbertus \& O. Reisinger, 1974. Observations ultrastructurales de la biodegradation d'une algae dans un ecosysteme aquatique. Bull. Acad. Soc. Lorraines Sci. 13 (2): 137-148.

Quershi, R. H., D. A. Jenkins, R. T. Davis \& J. A. Rees, 1969. Application of microprobe analysis to the study of phosphorus in soils. Nature, Lond. 221: 1142-1143.

Quigley, R. M. \& T. A. Ogunbadejo, 1974. Soil weathering, soil structure and engineering properties, Sarnia clay crust. In: G. K. Rutherford (Ed.), Soil microscopy, pp. 165-178. Limestone Press, Kingston, Ontario, Canada.

Reed, S. J. B., 1975. Electron microprobe analysis. Cambridge University Press, London, 400 pp.

Riezebos, P. A., 1974. Scanning electron microscopical observations on weakly cemented Miocene sands. Geol. Mijnb. 53 (4): 109-122.

Riezebos, P. A. \& L. van der Waals, 1974. Silt-sized quartz particles: A proposed source. Sedim. Geol. 12: 279-285.

Righi, D., 1975. Etude au microscope électronique à balayage de champ et au microanalyseur à sonde électronique des revêtements et des agrégats organiques d'horizons $B$ spodiques. Bull. Ass. fr. Et. Sol 4: 315-321.

Robinson, C. F., 1973. Ion microprobe instrumentation. In: C. A. Anderson (Ed.), Microprobe analysis, pp. 507-530. J. Wiley, New York.

Rutherford, G. K., 1969. Initial study of the genesis of a laterite from Guyana using micromorphology and the lectron microprobe. In: Proc. 3rd int. Work. Meet. Soil Micromorphol. Zeszyty Problemowe Postepów Nauk Rolniczych: 387-397.

Sawhney, B. L., 1968. Cesium uptake by vermiculite flakes: electron microprobe and X-ray diffraction analyses. Abstr. 17th a. Clay Miner. Conf. (Bloomington, Indiana): 22-23. 
Schmidt-Lorenz R., 1974a. Lateritisierung - ein Sonderfall der Ferrallitisierung. Mitt. Dt. bodenkd. Ges. 20: 68-79.

Schmidt-Lorenz R., 1974b. Nachweis von Laterit-Spuren in paläopedogenem Material, aufgezeigt an Beispielen aus Mitteleuropa. Mitt. Dt. bodenkd. Ges. 20: 114-122.

Seddoh, F. K. \& G. Pedro, 1974. Caractérisation des différents stades de transformation des biotites et biotites chloritisées dans les arènes granitiques du Morvan. Bull. Gr. fr. Argiles 26 (1): $107-125$.

Seiler, H., 1974. Neue Entwicklungen bei der Abbildung und Analyse von Festkörper-Oberflächen. Chemie-Ing.-Tech. 46 (19): 797-804.

Sheeran, D. E. \& R. N. Yong, 1974. Participation of micro and macrofabric in the energy characterization of clays. In: G. K. Rutherford (Ed.), Soil microscopy, pp. 179-189. Limestone Press, Kingston, Ontario, Canada.

Singer, A., 1975. A Cretaceous laterite in the Negev desert, southern Israel. Geol. Mag. 112 (2): 151-162.

Smart, P., 1974. Electron microscope methods in soil micromorphology. In: G. K. Rutherford (Ed.), Soil microscopy, pp. 190-206. Limestone Press, Kingston, Ontario, Canada.

Sridhar, K., M. L. Jackson \& R. N. Clayton, 1975. Quartz oxygen isotopic stability in relation to isolation from sediments and diversity of source. Proc. Soil Sci. Soc. Am. 39 (6): 1209-1213.

Stoops, G., 1974. Optical and electron microscopy. A comparison of their principles and their use in micropedology. In: G. K. Rutherford (Ed.), Soil microscopy, pp. 101-118. Limestone Press, Kingston, Ontario, Canada.

Sweatmann, T. R. \& J. V. P. Long, 1969. Quantitative electron-probe microanalysis of rock forming minerals. J. Petrol. 10: 332-379.

Tan, K. H., H. F. Perkins \& R. A. McCreery, 1975. Amorphous and crystalline clays in volcanic ash soils of Indonesia and Costa Rica. Soil. Sci. 119 (6): 431-440.

Tovey, K. N., 1974. Some applications of electron microscopy to soil engineering. In: G. K. Rutherford (Ed.), Soil microscopy, pp. 119-142. Limestone Press, Kingston, Ontario, Canada.

Tovey, K. N. \& Kwong Yan Wong, 1974. Some aspects of quantitative measurement from electron micrographs of soil structures. In: G. K. Rutherford (Ed.), Soil microscopy, pp. 207222. Limestone Press, Kingston, Ontario, Canada.

Veen, A. W. L. \& P. Maaskant, 1971. Electron microprobe analysis of plasma in an impervious horizon of a tropical groundwater podzol. Geoderma 6: 101-107.

Verheye, W. \& G. Stoops, 1975. Nature and evolution of soils developed on the granite complex in the subhumid tropics (Ivory Coast). II. Micromorphology and mineralogy. Pédologie 25 (1): $40-55$.

Wieder, M. \& D. H. Yaalon, 1974. Effect of matrix composition on carbonate nodule crystallization. Geoderma 11: 95-121.

Wilding, L. P. \& L. R. Drees, 1973. Scanning electron microscopy of opaque opaline forms isolated from forest soils in Ohio. Proc. Soil. Sci. Soc. Am. 37 (4): 647-650.

Wilding, L. P. \& L. R. Drees, 1974. Contribution of forest opal and associated crystalline phases to fine silt and clay fractions of soils. Clays \& Clay Miner. 22 (3): 295-306.

Wilding, L. P. \& H. D. Geissinger, 1973. Correlative light optical and scanning electron microscopy of minerals: A methodology study. J. Sedim. Petr. 43 (1): 280-286.

Wilson, M. J., 1975. Chemical weathering of some primary rock-forming minerals. Soil Sci. 119 (5): 349-355. 